\title{
Prevalence and phylogeny of Chlamydiae and hemotropic mycoplasma species in captive and free-living bats
}

Janine Fritschi ${ }^{1,2}$, Hanna Marti ${ }^{1,2}$, Helena M. B. Seth-Smith ${ }^{1}$, Sébastien Aeby ${ }^{3}$, Gilbert Greub ${ }^{3}$, Marina L. Melii ${ }^{2,4}$, Regina Hofmann-Lehmann ${ }^{2,4}$, Kristin Mühldorfer ${ }^{5}$, Nadine Stokar-Regenscheit $^{6}$, Danja Wiederkehr ${ }^{7}$, Paola Pilo ${ }^{8}$, Peggy Rüegg- Van Den Broek ${ }^{9}$ and Nicole Borel ${ }^{1,2^{*}}$

\begin{abstract}
Background: Bats are hosts for a variety of microorganisms, however, little is known about the presence of Chlamydiales and hemotropic mycoplasmas. This study investigated 475 captive and free-living bats from Switzerland, Germany, and Costa Rica for Chlamydiales and hemotropic mycoplasmas by PCR to determine the prevalence and phylogeny of these organisms.

Results: Screening for Chlamydiales resulted in a total prevalence of $31.4 \%$. Positive samples originated from captive and free-living bats from all three countries. Sequencing of 15 samples allowed the detection of two phylogenetically distinct groups. These groups share sequence identities to Chlamydiaceae, and to Chlamydia-like organisms including Rhabdochlamydiaceae and unclassified Chlamydiales from environmental samples, respectively.

PCR analysis for the presence of hemotropic mycoplasmas resulted in a total prevalence of $0.7 \%$, comprising free-living bats from Germany and Costa Rica. Phylogenetic analysis revealed three sequences related to other unidentified mycoplasmas found in vampire bats and Chilean bats.

Conclusions: Bats can harbor Chlamydiales and hemotropic mycoplasmas and the newly described sequences in this study indicate that the diversity of these bacteria in bats is much larger than previously thought. Both, Chlamydiales and hemotropic mycoplasmas are not restricted to certain bat species or countries and captive and free-living bats can be colonized. In conclusion, bats represent another potential host or vector for novel, previously unidentified, Chlamydiales and hemotropic mycoplasmas.
\end{abstract}

Keywords: Chlamydiales, Hemotropic mycoplasmas, Hemoplasmas, Bats, DNA, qPCR

\footnotetext{
* Correspondence: Nicole.borel@uzh.ch

'Institute of Veterinary Pathology, Vetsuisse Faculty, University of Zurich, Zurich, Switzerland

${ }^{2}$ Center for Clinical Studies, Vetsuisse Faculty, University of Zurich, Zurich, Switzerland

Full list of author information is available at the end of the article
}

(c) The Author(s). 2020 Open Access This article is licensed under a Creative Commons Attribution 4.0 International License, which permits use, sharing, adaptation, distribution and reproduction in any medium or format, as long as you give appropriate credit to the original author(s) and the source, provide a link to the Creative Commons licence, and indicate if changes were made. The images or other third party material in this article are included in the article's Creative Commons licence, unless indicated otherwise in a credit line to the material. If material is not included in the article's Creative Commons licence and your intended use is not permitted by statutory regulation or exceeds the permitted use, you will need to obtain permission directly from the copyright holder. To view a copy of this licence, visit http://creativecommons.org/licenses/by/4.0/ The Creative Commons Public Domain Dedication waiver (http://creativecommons.org/publicdomain/zero/1.0/) applies to the data made available in this article, unless otherwise stated in a credit line to the data. 


\section{Background}

Bats of the order Chiroptera are of increasing interest as potential reservoirs and vectors of pathogens. They possess unique characteristics among mammals, such as the ability to fly. Their extensive mobility, combined with their roost plasticity, nesting behavior and broad food range allows transport of pathogens to many different animal species in various locations [1]. It has been shown that bats are hosts for a multitude of different microorganisms that include viruses, bacteria, parasites and fungi. Several of these infectious agents are common to humans and domestic animals. The pathogenic potential of some bacterial species has been confirmed for bats, but the knowledge regarding the impact of such microorganisms on bat hosts is limited. In addition, knowledge on the natural microbiota of bats is scarce [2].

Chlamydiae are highly successful animal and human pathogens. Their taxonomic structure is composed of the order Chlamydiales, which consists of the nine families Parachlamydiaceae, Waddliaceae, Simkaniaceae, Rhabdochlamydiaceae, Criblamydiaceae, Piscichlamydiaceae, Clavichlamydiaceae and Parilichlamydiaceae, collectively referred to as Chlamydia-like organisms, and the Chlamydiaceae [3-5]. Chlamydiae are obligate intracellular bacteria with a biphasic developmental cycle. This cycle is characterized by the infectious but metabolically less active elementary body, which infects susceptible host cells, and the intracellular reticulate body, which undergoes binary fission [6]. As an inclusion fills with progeny, the reticulate bodies condense back into elementary bodies and are released by host cell rupture or by fusion of the inclusion membrane with the host cell plasma membrane. Chlamydiae are disseminated by aerosol or contact, requiring no alternative vector [4].

In 2005 and 2015, two novel Chlamydia-like organisms, Waddlia malaysiensis and Waddlia cocoyoc were detected in fruit bats in Malaysia and Mexico, respectively [7, 8]. In 2016, members of the order Chlamydiales were detected in the fecal bacterial microbiota of Daubenton's bats in Finland [9].

Hemotropic mycoplasmas (hemoplasmas) are considered to be emerging or re-emerging zoonotic pathogens. They are classified in the order Mycoplasmatales, family Mycoplasmataceae and genus Mycoplasma. They are small, pleomorphic bacteria without a cell wall and parasitize red blood cells $[10,11]$. The transmission routes of hemoplasmas are not yet fully understood, but they are thought to be transmitted through blood, saliva and possibly also arthropods [10, 12-14]. Hemoplasmas are able to cause acute infectious anemia or various chronic diseases in farm animals $[15,16]$, wild animals $[17,18]$, pets [14] and humans [19]. The extent of clinical manifestations ranges from asymptomatic to lifethreatening [10].
From 2014 to 2017, four studies to determine the prevalence of hemoplasmas in various bat species were conducted [20-23]. The prevalence ranged from $18.5 \%$ in Brazil to $96.8 \%$ in Spain and sequences indicating new species or new genotypes were identified [20-23].

The objective of this study was to investigate the prevalence and phylogenetic positioning of Chlamydiae and hemotropic mycoplasmas species in 475 captive and free-living bats from six families and 28 species from Switzerland, Germany, and Costa Rica (Table 1).

\section{Results \\ Polymerase chain reaction (PCR) and sequencing results for Chlamydiales}

A total of $166 / 1021$ DNA samples (16.3\%) originating from 149/475 bats (31.4\%) were positive for Chlamydiales DNA by real-time PCR. Of these 166 samples, 15 samples had a $\mathrm{Ct}$ value below 35.0 and were therefore sequenced, resulting in 17 consensus sequences comprising two to four sequences (Table 2). A BLASTn analysis and phylogenetic trees (Fig. 1) of these sequences revealed two groups and suggest that these sequences may represent two novel species-level lineages.

Group one contained eight consensus sequences from six free-living bats (F18-0155.54, F18-0155.98, E 148/ 07, E 155/07, E 161/07 and E 179/07) originating from Switzerland and Germany that carry bacteria belonging to the Chlamydiaceae-family according to the classification scheme by Pillonel et al. [24] and phylogenetic analysis. The best BLASTn hits of the sequences obtained by the 16S-pan-PCR alone (95-201 base pair, bp) were primarily with sequences from uncultured Chlamydiales bacterium clone 1778 (GenBank accession number KU664271.1), from Chlamydiales bacterium isolate CL gt1 (GenBank accession number MF620054.1) and from Chlamydia psittaci strain AMK (GenBank accession number CP047319.1). The best BLASTn hits for consensus sequences obtained from both the 16S-IGF/IGRPCR and the 16S-pan-PCR (size: 281-475 bp) was Chlamydia pecorum strain B0-Maeda (GenBank accession number AB001775.1) and Chlamydophila pecorum strain Ov/IPA (GenBank accession number D85716.1). Within this group phylogenetic analysis of $16 \mathrm{~S}$ ribosomal ribonucleid acid (16S rRNA) and $23 \mathrm{~S}$ ribosomal ribonucleid acid (23S rRNA) gene sequences shows that they cluster and belong to a novel branch most closely related to the Chlamydia genus (Table 2, Fig. 1a-c). Further published sequences from bats are also closely related to these [9] (Fig. 1b,c).

Group two contained 9 sequences from bacteria within four captive and five free-living bats (Sample IDs 52, 95, F18-0155.121, F18-0155.130, F18-0155.145, E 4/08, E 6/ 08, E 148/07, E 161/07, E197/07 and E 18/07) originating from Switzerland, Germany, and Costa Rica. They are 
Table 1 Sampled bats categorized according to origin, family, species and number of animals

\begin{tabular}{|c|c|c|c|c|}
\hline Origin & & Family & Species & Number of Animals \\
\hline \multirow[t]{8}{*}{$\overline{\text { Captive }}$} & Switzerland & Phyllostomidae & Carollia perspicillata & 89 \\
\hline & Germany & Phyllostomidae & Carollia perspicillata & 13 \\
\hline & & & Glossophaga commissarisi & 2 \\
\hline & & & Glossophaga soricina & 2 \\
\hline & & & Phyllostomus discolor & 5 \\
\hline & & Pteropodidae & Eidolon helvum helvum & 4 \\
\hline & & & Rousettus aegyptiacus & 1 \\
\hline & & Megadermatidae & Megaderma lyra & 1 \\
\hline \multirow[t]{32}{*}{ Free-living } & Switzerland & Vespertilionidae & Eptesicus nilssonii & 1 \\
\hline & & & Eptesicus sp. & 1 \\
\hline & & & Hypsugo savii & 1 \\
\hline & & & Myotis daubentonii & 2 \\
\hline & & & Myotis myotis & 18 \\
\hline & & & Myotis mystacinus & 8 \\
\hline & & & Myotis nattereri & 2 \\
\hline & & & Nyctalus leisleri & 2 \\
\hline & & & Nyctalus noctula & 6 \\
\hline & & & Pipistrellus kuhlii & 28 \\
\hline & & & Pipistrellus nathusii & 18 \\
\hline & & & Pipistrellus pipistrellus & 123 \\
\hline & & & Pipistrellus pygmaeus & 4 \\
\hline & & & Pipistrellus sp. & 47 \\
\hline & & & Plecotus auritus & 4 \\
\hline & & & Plecotus sp. & 3 \\
\hline & & & Vespertilio murinus & 8 \\
\hline & & Rhinolophidae & Rhinolophus ferrumequinum & 2 \\
\hline & & & Rhinolophus hipposideros & 2 \\
\hline & & Unknown & Unknown & 5 \\
\hline & Germany & Vespertilionidae & Barbastella barbastellus & 2 \\
\hline & & & Eptesicus nilssonii & 6 \\
\hline & & & Eptesicus serotinus & 15 \\
\hline & & & Nyctalus leisleri & 1 \\
\hline & & & Nyctalus noctula & 16 \\
\hline & & & Plecotus auritus & 7 \\
\hline & & & Vespertilio murinus & 9 \\
\hline & Costa Rica & Phyllostomidae & Artibeus watsoni & 1 \\
\hline & & & Carollia perspicillata & 1 \\
\hline & & & Glossophaga commissarisi & 13 \\
\hline & & Vespertilionidae & Rhogeessa io & 1 \\
\hline & & Emballonuridae & Saccopteryx bilineata & 1 \\
\hline Total & & & & 475 \\
\hline
\end{tabular}


Table 2 Sequencing results of Chlamydiales and hemotropic mycoplasmas positive bats including the top BLASTn hit (query cover 98-100\%) and identity results

\begin{tabular}{|c|c|c|c|c|c|}
\hline Sample ID & $\begin{array}{l}\text { Organ } \\
\text { source }\end{array}$ & Bat species \& origin & Applied PCR (Product size) & Top BLASTn hit (Accession No.) & Identity \\
\hline 52 & Spleen & $\begin{array}{l}\text { Carollia perspicillata } \\
\text { (Switzerland, captive) }\end{array}$ & 16S-pan-PCR (114/200 bp) & Uncultured Chlamydiales (MH119787.1) & $99.1 \%$ \\
\hline 95 & Liver & $\begin{array}{l}\text { Carollia perspicillata } \\
\text { (Switzerland, captive) }\end{array}$ & 16S-pan-PCR (181/200 bp) & Uncultured Chlamydiales (JX083073.1) & $91.7 \%$ \\
\hline $\begin{array}{l}\text { F18- } \\
0155.54\end{array}$ & FFPE & $\begin{array}{l}\text { Myotis myotis } \\
\text { (Switzerland, free- } \\
\text { living) }\end{array}$ & $\begin{array}{l}\text { 16S-IGF/IGR-PCR + } \\
\text { 16S-pan-PCR (475/478 bp) }\end{array}$ & Chlamydia pecorum (AB001775.1) & $93.1 \%$ \\
\hline $\begin{array}{l}\text { F18- } \\
0155.98\end{array}$ & FFPE & $\begin{array}{l}\text { Pipistrellus pipistrellus } \\
\text { (Switzerland, free- } \\
\text { living) }\end{array}$ & $\begin{array}{l}\text { 16S-IGF/IGR-PCR + } \\
\text { 16S-pan-PCR (510/478 bp) }\end{array}$ & Chlamydophila pecorum (D85716.1) & $93.1 \%$ \\
\hline $\begin{array}{l}\text { F18- } \\
0155.121\end{array}$ & FFPE & $\begin{array}{l}\text { Pipistrellus sp. } \\
\text { (Switzerland, free- } \\
\text { living) }\end{array}$ & $\begin{array}{l}\text { 16S-IGF/IGR-PCR + } \\
\text { 16S-pan-PCR (281/478 bp) }\end{array}$ & Uncultured Chlamydiales (MK112598.1) & $92.3 \%$ \\
\hline $\begin{array}{l}\text { F18- } \\
0155.130\end{array}$ & FFPE & $\begin{array}{l}\text { Pipistrellus pipistrellus } \\
\text { (Switzerland, free- } \\
\text { living) }\end{array}$ & 16S-pan-PCR (104/200 bp) & Uncultured Chlamydiales (MF440154.1) & $100.0 \%$ \\
\hline $\begin{array}{l}\text { F18- } \\
0155.145\end{array}$ & FFPE & $\begin{array}{l}\text { Pipistrellus pipistrellus } \\
\text { (Switzerland, free- } \\
\text { living) }\end{array}$ & 16S-pan-PCR (112/200 bp) & Uncultured bacterium (LC336010.1) & $99.1 \%$ \\
\hline E 4/08 & Intestine & $\begin{array}{l}\text { Glossophaga soricina } \\
\text { (Germany, captive) }\end{array}$ & 16S-pan-PCR (155/200 bp) & Uncultured bacterium (AB618438.1) & $97.4 \%$ \\
\hline E 6/08 & Intestine & $\begin{array}{l}\text { Glossophaga soricina } \\
\text { (Germany, captive) }\end{array}$ & 16S-pan-PCR (159/200 bp) & Uncultured bacterium (KY692835.1) & $96.9 \%$ \\
\hline \multirow[t]{2}{*}{ E 148/07 } & Intestine & $\begin{array}{l}\text { Nyctalus noctula } \\
\text { (Germany, free-living) }\end{array}$ & $\begin{array}{l}\text { 16S-IGF/IGR-PCR + } \\
\text { 16S-pan-PCR (460/478 bp) }\end{array}$ & Chlamydia pecorum (AB001775.1) & $93.5 \%$ \\
\hline & & & 23SIG-PCR (519/700 bp) & Uncultured Chlamydiales (KU664232.1) & $95.6 \%$ \\
\hline E 155/07 & Intestine & $\begin{array}{l}\text { Nyctalus noctula } \\
\text { (Germany, free-living) }\end{array}$ & 16S-pan-PCR (95/200 bp) & Chlamydia psittaci (CP047319.1)a & $95.8 \%$ \\
\hline \multirow[t]{2}{*}{ E 161/07 } & Intestine & $\begin{array}{l}\text { Eptesicus serotinus } \\
\text { (Germany, free-living) }\end{array}$ & $\begin{array}{l}\text { 16S-IGF/IGR-PCR + } \\
\text { 16S-pan-PCR (506/478 bp) }\end{array}$ & Chlamydia pecorum (AB001775.1) & $94.1 \%$ \\
\hline & & & 23SIG-PCR (522/700 bp) & Uncultured Chlamydiales (KU664232.1) & $95.6 \%$ \\
\hline E 179/07 & Intestine & $\begin{array}{l}\text { Nyctalus noctula } \\
\text { (Germany, free-living) }\end{array}$ & 16S-pan-PCR (201/200 bp) & Chlamydiales bacterium (MF620054.1) & $97.4 \%$ \\
\hline E 197/07 & Intestine & $\begin{array}{l}\text { Vespertilio murinus } \\
\text { (Germany, free-living) }\end{array}$ & 16S-pan-PCR (158/200 bp) & Uncultured Chlamydiales (HQ721227.1) & $99.4 \%$ \\
\hline E 18/07 & Intestine & $\begin{array}{l}\text { Rhogeessa io } \\
\text { (Costa Rica, free- }\end{array}$ & 16S-IGF/IGR-PCR (269/278 bp) & $\begin{array}{l}\text { Rhabdochlamydiaceae bacterium } \\
(\text { MF620051.1) }\end{array}$ & $96.3 \%$ \\
\hline
\end{tabular}

\section{Hemotropic Mycoplasmas}

\begin{tabular}{|c|c|c|c|}
\hline Sample ID & $\begin{array}{l}\text { Organ } \\
\text { source }\end{array}$ & Bat species \& origin & Method \\
\hline E 173/07 & Spleen & $\begin{array}{l}\text { Nyctalus noctula } \\
\text { (Germany, free-living) }\end{array}$ & $\begin{array}{l}\text { HemMycop (41/938 + 322/1420)-PCR (1151/ } \\
1901 \text { bp) }\end{array}$ \\
\hline E 190/07 & Spleen & $\begin{array}{l}\text { Vespertilio murinus } \\
\text { (Germany, free-living) }\end{array}$ & $\begin{array}{l}\text { HemMycop (41/938 + 322/1420)-PCR (1196/ } \\
1901 \text { bp) }\end{array}$ \\
\hline E 70/06 & Spleen & $\begin{array}{l}\text { Glossophaga } \\
\text { commissarisi } \\
\text { (Costa Rica, free- } \\
\text { living) }\end{array}$ & HemMycop41/938-PCR (774/871bp) \\
\hline
\end{tabular}

\section{Top BLASTn hit (Accession No.) Identity}

Uncultured Mycoplasma sp. $\quad 97.3 \%$ (MK295631.1)

Uncultured Mycoplasma sp. (MK295631.1)

Uncultured Mycoplasma sp. (KY932722.1) 96.3\%

\section{Others}

F18- $\quad$ FFPE

0155.55

$$
\begin{aligned}
& \text { Pipistrellus kuhlii } \\
& \text { (Switzerland, free- } \\
& \text { living) }
\end{aligned}
$$

HemMycop (41/938 + 322/1420)-PCR (741/ 1901 bp)
Uncultured bacterium (MK372594.1)

$99.4 \%$ 
Table 2 Sequencing results of Chlamydiales and hemotropic mycoplasmas positive bats including the top BLASTn hit (query cover 98-100\%) and identity results (Continued)

\begin{tabular}{|c|c|c|c|c|c|}
\hline Sample ID & $\begin{array}{l}\text { Organ } \\
\text { source }\end{array}$ & Bat species \& origin & Applied PCR (Product size) & Top BLASTn hit (Accession No.) & Identity \\
\hline $\begin{array}{l}\text { F18- } \\
0155.63\end{array}$ & FFPE & $\begin{array}{l}\text { Pipistrellus pipistrellus } \\
\text { (Switzerland, free- } \\
\text { living) }\end{array}$ & $\begin{array}{l}\text { HemMycop41/938-PCR } \\
\text { (743/871 bp) }\end{array}$ & Uncultured bacterium (MK372594.1) & $99.5 \%$ \\
\hline $\begin{array}{l}\text { F18- } \\
0155.70\end{array}$ & FFPE & $\begin{array}{l}\text { Nyctalus noctula } \\
\text { (Switzerland, free- } \\
\text { living) }\end{array}$ & $\begin{array}{l}\text { HemMycop (41/938 + 322/1420)-PCR } \\
\text { (1182/1901 bp) }\end{array}$ & $\begin{array}{l}\text { Uncultured Sphingomonadaceae } \\
\text { (EF019656.1) }\end{array}$ & $92.8 \%$ \\
\hline $\begin{array}{l}\text { F18- } \\
0155.99\end{array}$ & FFPE & $\begin{array}{l}\text { Pipistrellus kuhlii } \\
\text { (Switzerland, free- } \\
\text { living) }\end{array}$ & $\begin{array}{l}\text { HemMycop (41/938 + 322/1420)-PCR } \\
\text { (886/1901 bp) }\end{array}$ & Uncultured bacterium (MK372594.1) & $99.5 \%$ \\
\hline $\begin{array}{l}\text { F18- } \\
0155.102\end{array}$ & FFPE & $\begin{array}{l}\text { Pipistrellus kuhlii } \\
\text { (Switzerland, free- } \\
\text { living) }\end{array}$ & $\begin{array}{l}\text { HemMycop (41/938 + 322/1420)-PCR } \\
\text { (503/1901 bp) }\end{array}$ & Bradyrhizobium sp. (MT102777.1) & $98.8 \%$ \\
\hline $\begin{array}{l}\text { F18- } \\
0155.110\end{array}$ & FFPE & $\begin{array}{l}\text { Myotis daubentonii } \\
\text { (Switzerland, free- } \\
\text { living) }\end{array}$ & $\begin{array}{l}\text { HemMycop (41/938 + 322/1420)-PCR } \\
\text { (1266/1901 bp) }\end{array}$ & Altererythrobacter sp. (MK574878.1) & $92.6 \%$ \\
\hline $\begin{array}{l}\text { F18- } \\
0155.113\end{array}$ & FFPE & $\begin{array}{l}\text { Nyctalus noctula } \\
\text { (Switzerland, free- } \\
\text { living) }\end{array}$ & $\begin{array}{l}\text { HemMycop (41/938 + 322/1420)-PCR } \\
\text { (748/1901 bp) }\end{array}$ & Bradyrhizobium sp. (MG588424.1) & $89.3 \%$ \\
\hline $\begin{array}{l}\text { F18- } \\
0155.116\end{array}$ & FFPE & $\begin{array}{l}\text { Pipistrellus sp. } \\
\text { (Switzerland, free- } \\
\text { living) }\end{array}$ & $\begin{array}{l}\text { HemMycop (41/938 + 322/1420)-PCR } \\
\text { (950/1901 bp) }\end{array}$ & Bradyrhizobium sp. (MK638083.1) & $99.9 \%$ \\
\hline E 196/07 & Spleen & $\begin{array}{l}\text { Eptesicus nilssonii } \\
\text { (Germany, free-living) }\end{array}$ & $\begin{array}{l}\text { HemMycop (41/938 + 322/1420)-PCR } \\
\text { (951/1901 bp) }\end{array}$ & Uncultured bacterium (MK372594.1) & $98.9 \%$ \\
\hline
\end{tabular}

${ }^{a}$ Chlamydial sequences assigned to group 1

${ }^{b}$ Chlamydial sequences assigned to group 2

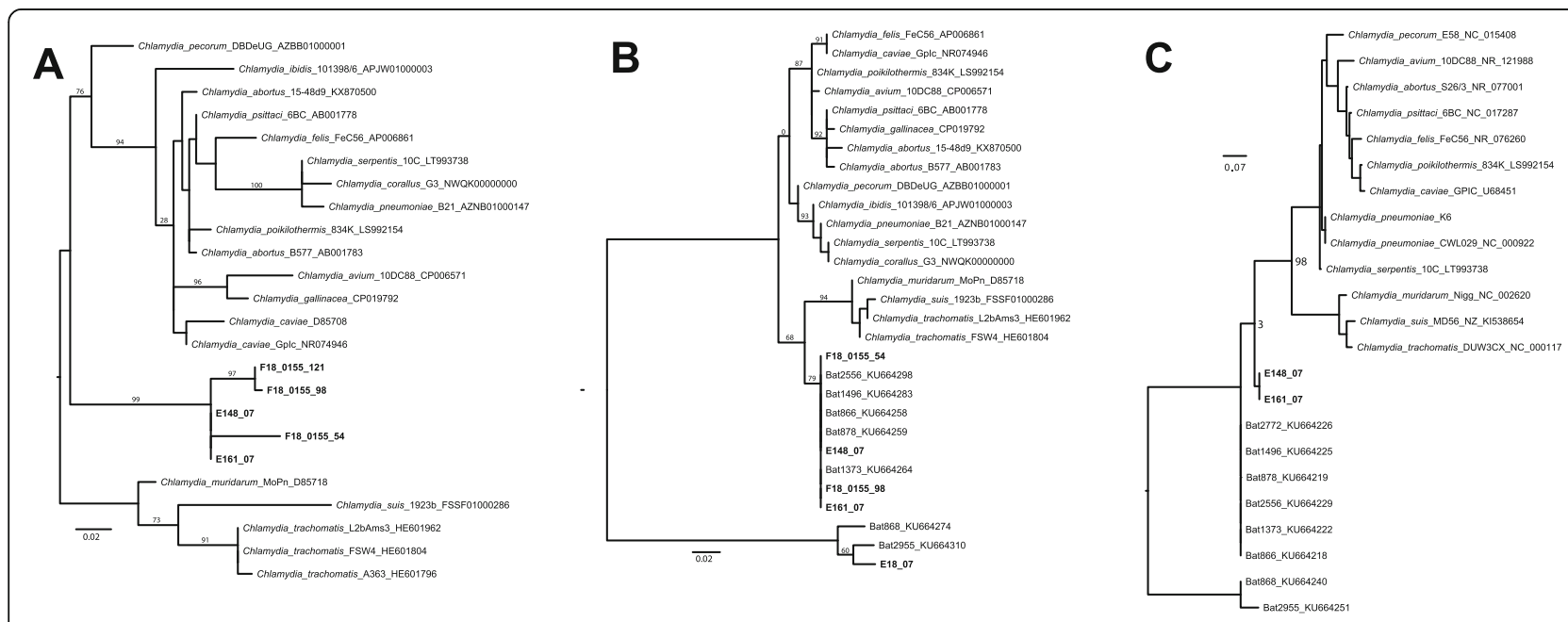

Fig. 1 Phylogenetic trees based on partial sequences of the 165 and the $23 S$ rRNA genes that show the relationships of the sequences obtained in this study and publicly available sequences of Chlamydia species and selected published sequences found in bats reflecting the phylogenetic relationship between known Chlamydia species based on nine genes [24]. a Phylogeny of chlamydial 16S rRNA gene, 284 bp covering V1 - V2, including all novel sequences and illustrating that they fall together within a novel clade. b Phylogeny of chlamydial 165 rRNA gene, 200 bp covering V3, relating available novel sequences to those previously found in bat samples and illustrating that these samples are closely related to previous bat samples over this region. c. Phylogeny of chlamydial $23 \mathrm{~S}$ rRNA gene, $530 \mathrm{bp}$, relating available novel sequences to those previously found in bat samples and illustrating differences between the novel samples and previous bat samples across this region. Bat samples were selected from those published in Hokynar et al. [9] to reflect closely related samples and outgroup "Rhabdochlamydiaceae-like" samples. Bootstraps of 100 replicates are shown on key branches. Scale bar shows number of substitutions per site. Samples from this study are shown in bold 
closely related to sequences from uncultured Chlamydiales and from the Rhabdochlamydiaceae bacterium isolate P gt1 (GenBank accession number MF620051.1) (Table 2). Not all sequences gave clearly interpretable traces: one 16S rRNA sequence gave sufficient quality for phylogenetic analysis and shows this relationship to previously characterized sequences from bats [9] (Fig. 1b).

\section{PCR and sequencing results for hemotropic mycoplasmas} A total of $15 / 475$ DNA samples (3.2\%) originating from $15 / 462$ bats $(3.3 \%)$ tested positive or questionably positive for hemotropic mycoplasmal DNA by at least one of the two real-time PCRs used for screening. All 15 samples were also positive by conventional 16S rRNA gene PCR and were sent for sequencing, which resulted in 12 sequences that were readable in both directions. BLAST analysis revealed that three sequences fall in two clades that were closely related to either uncultured
Mycoplasma sp. clone 20180131LOC1.16 or clone D159 (GenBank accession numbers MK295631.1 and KY932722.1) with a sequence identity of 96.3 to $98.6 \%$ (Table 2). The phylogenetic tree constructed from these $16 \mathrm{~S}$ rRNA gene sequences (Fig. 2) shows that they are closely related to previously published sequences from vampire bat samples [23] and sequences from Chilean bat samples [25].

The remaining nine sequences were closely related to Proteobacteria by BLAST analysis (Table 2 "Others").

\section{Discussion}

Bats are known to be important vectors and reservoirs for a multitude of different microorganisms such as lyssaviruses, henipaviruses [2], Leptospira sp. [26] and Bartonella spp. [27], but the knowledge regarding their potential role as carriers of other clinically significant pathogens or less common bacteria is limited. To date, the

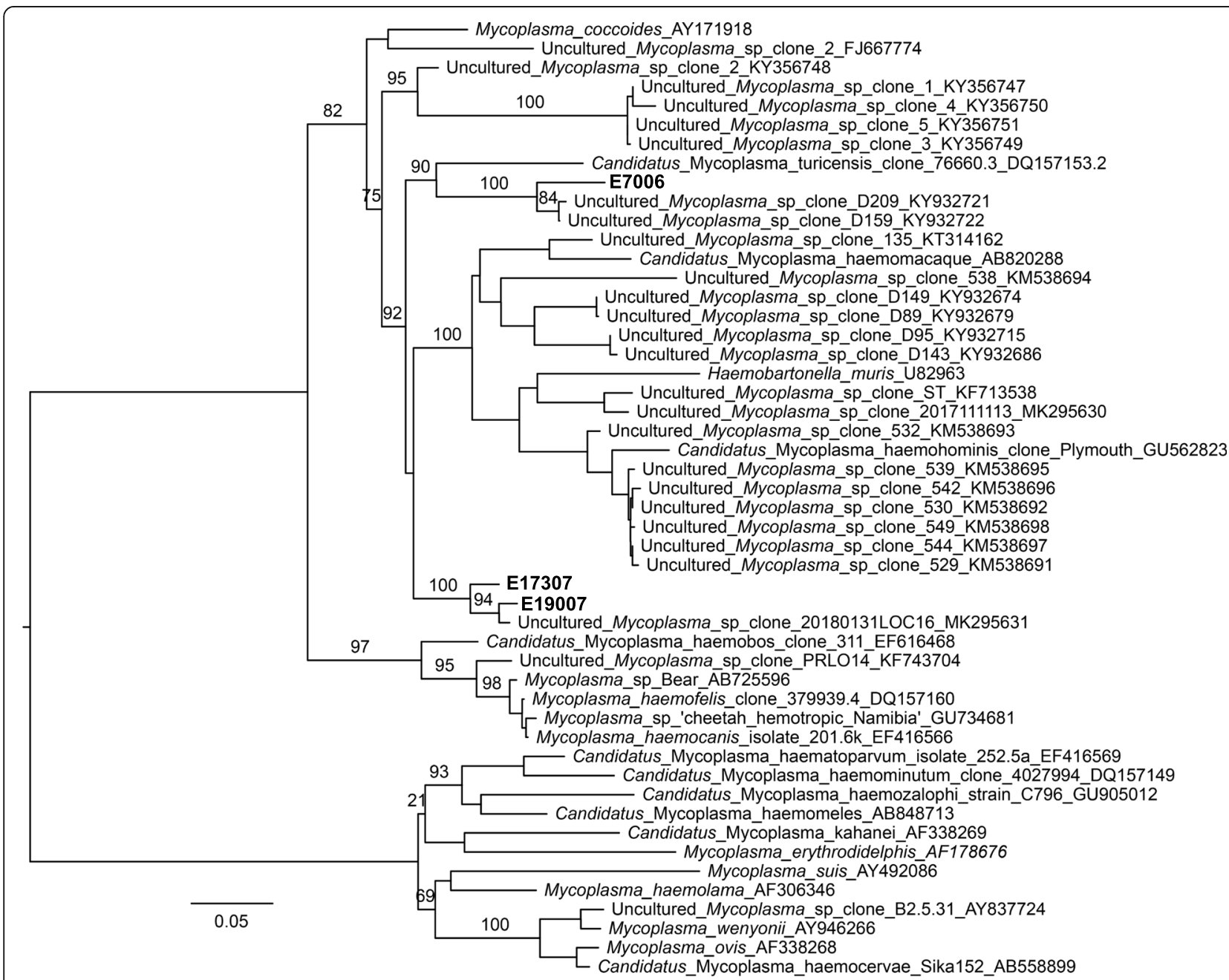

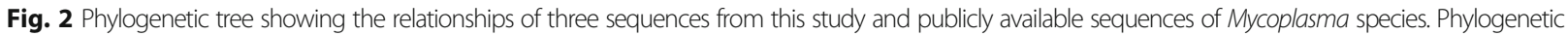
tree based on sequences obtained from PCR products of the $16 \mathrm{~S}$ rRNA gene of hemotropic mycoplasmas, 1252 bp (minimum 824 bp). Bootstraps of 100 replicates are shown on key branches. Scale bar shows number of substitutions per site. Samples from this study are shown in bold 
only Chlamydiales identified in bats are two Chlamydialike organisms: Waddlia malaysiensis [7] and Waddlia cocoyoc [8], isolated from fruit bats in Malaysia and Mexico, respectively, and members of the order Chlamydiales, isolated from a common bat species (Myotis daubentonii) in Finland [9].

\section{PCR and sequencing results for Chlamydiales}

Phylogenetic analysis of the sequences obtained in the present study resulted in the formation of two groups: Chlamydiaceae-like and Chlamydiales-like. Separation in these groups had been previously described in the study from Hokynar et al. [9]. However, a precise classification according to the scheme from Pillonel et al. [24] was not possible based on short amplicons retrieved in this study and also because only $16 \mathrm{~S}$ and $23 \mathrm{~S}$ rRNA gene products were sequenced. The phylogenetic trees showed that five samples from group one (Sample IDs F18-0155.54, F18-0155.98, E 148/07, E 161/07 and E 18/07) are closely related to the samples from Hokynar et al. and four of them (Sample IDs F18-0155.54, F180155.98, E 148/07 and E 161/07) form a novel clade within the Chlamydiaceae family. These five samples originated from free-living bats from Switzerland and Germany belonging to the bat species Myotis myotis, Pipistrellus pipistrellus, Nyctalus noctula and Eptesicus serotinus. Therefore, it can be said that this clade first discovered in Finland occurs also in other parts of Europe and colonizes various species of free-living insectivorous bats. In the present study, these Chlamydiae were detected directly in the inner organs; therefore, these bats might actually act as a host, meaning that the Chlamydiae are not merely prey-borne, as hypothesized by Hokynar et al. The latter study only investigated bat feces and insect material, inner organs were not available. Although the present study indicates the presence of chlamydial DNA in inner organs, such as the intestine, detection of replicating chlamydial organisms could not be assessed; Detection of replication would have required the attempt of isolation, which was hampered by the unavailability of fresh frozen tissue material. Chlamydial DNA might originate from the diet or represent colonization and/or real infection [9]. If the latter holds true, this would suggest that the different chlamydial species documented in bats might have a pathogenic role for the bats or that these bats act as vectors.

In a study by Hornok et al. [28], 196 individual and 25 pooled fecal samples collected from 19 bat species from Hungary and the Netherlands were investigated for the presence of chlamydial DNA; they all tested negative indicating that the prevalence of Chlamydiae in bats is highly variable in studies from neighboring countries. This observation suggests that, although this new Chlamydiae clade may occur in some parts of Europe, colonization or infection of bats is influenced by factors that remain to be defined. Methodological differences may play a part of these factors.

Also a Rhabdochlamydiaceae-like sequence was identified in a sample (E 18/07) taken from a free-living bat from Costa Rica, which formed another novel clade with bat samples from Hokynar et al. [9] in the phylogenetic tree (E18_07). The remaining bat samples, similar to chlamydial sequences from environmental samples retrieved from the NCBI database, originated from captive and freeliving bats from Switzerland and Germany. Chlamydialike organisms are commonly present in water and inside amoebae [29-31], and have also been observed in ticks $[32,33]$ and fleas [34]. Thus, it is difficult to guess, which of these chlamydial putative vectors (amoebae or ticks) is the more likely at play as reservoir and vector.

In previous studies from Chua et al. [7] and Piérle et al. [8], two novel Chlamydia-like organisms belonging to the Waddliaceae family and named Waddlia malaysiensis and Waddlia cocoyoc were isolated from fruit bats from Malaysia and the municipality Cocoyoc in Mexico. These regions have a tropical climate, whereas a temperate climate predominates in Switzerland and Germany. In this study, bats from a tropical climate (Costa Rica) were analysed as well, but compared to the two other studies $(\mathrm{n}=$ 206 and $n=38)$ our sample size from Costa Rica $(n=17)$ was small. Another reason for the absence of Waddliaceae in bats of this study might the different sample type. Waddlia malaysiensis was first detected in urine samples from bats [7] but we did not investigate urine in this study. Waddlia cocoyoc was detected in DNA from the skin and in infected Vero and BHK 21 cells, but also caused severe lesions in lungs and spleen [8]. Therefore, it can be assumed that bacterial DNA would have been detected in these two organs if bacteria were present. The two isolates from Mexico and Malaysia might be bound to the regions and/or the climate.

In this study as well as in the studies from Hokynar et al. and Chua et al., only short fragments of the $16 \mathrm{~S}$ rRNA and 23S rRNA genes were amplified, as many of the samples in the present study were only available as FFPE samples because the bats had died in the wild and were subsequently collected and sampled, therefore preventing detailed classification.

\section{PCR and sequencing results for Mycoplasmatales}

In the current study, three sequences were closely related to uncultured Mycoplasma sp. and nine sequences were closely related to Proteobacteria. The amplification of Proteobacteria-like sequences might be the result of unspecific primer binding yielding false-positive PCR amplification.

The three sequences related to uncultured $\mathrm{Myco}$ plasma sp. originated from the samples of free-living 
bats from Germany and Costa Rica belonging to the bat species Nyctalus noctula, Vespertilio murinus and Glossophaga commissarisi. Consequently, different species from the bat families Vespertilionidae and Phyllostomidae can harbor hemotropic mycoplasmas. The presence of hemoplasmal DNA could be only confirmed in freeliving bats, which is in agreement with the presumed transmission pathways of hemotropic mycoplasmas through blood, saliva and arthropods [10, 12-14]. The captive bats were isolated from the environment and thus arthropod contact was at least partially excluded or reduced. Moreover, none of them were sanguivory bats and therefore do not bite other animals living in the enclosure. Consequently, transmission by blood, saliva and arthropods is very unlikely in captive bats.

The phylogenetic tree shows a close relationship between the sequences of the German bats among each other (E17307 and E19007) and a sequence from a Chilean bat [25]. The sequence from Costa Rican bat (E7006), on the other hand, was more closely related to sequences of vampire bats from Peru and Belize [23]. Vampire bats and the Commissaris's long-tongued bat (Glossophaga commissarisi) belong to the family of leafnosed bats and Peru, Belize and Costa Rica are geographically close to each other strengthening the high degree of relationship in the phylogenetic tree.

In other studies by Ikeda et al. [20], Mascarelli et al. [21], Millan et al. [22] and Volokhov et al. [23], a much higher mycoplasmal prevalence (18.5 to $97 \%$ ) was found than in the present study $(0.7 \%)$, despite partially similar numbers of samples. A similar prevalence $(1.8 \%)$ was only reported in the study by Hornok et al. [28]. Millan et al. suggested that subclinical infections with mycoplasmas in bats are common. This may be related to distinct climatic conditions and thus different arthropod activity, which are suspected to act as vectors of hemotropic mycoplasmas. In all studies, only fragments of the $16 \mathrm{~S}$ rRNA encoding gene were sequenced and then combined into contigs to optimize the chances of getting a larger 16S rRNA encoding gene sequence for further analysis. This study gives insight into the diversity of hemotropic mycoplasmas in different bat species from three geographical regions, although a more detailed description of the sequences and a more precise taxonomical classification were not possible.

Bats belong to the superorder of the Laurasiatheria and therefore are more closely related to carnivores, even-toed and odd-toed ungulates, than to rodents and primates, which belong to the superorder of the Euarchontoglires. While the relationship of other hemotropic mycoplasmas represented in the phylogenetic tree (Fig. 2) roughly corresponds to that of the mammalian classification, Mycoplasma of bats are the only ones to classify quite differently. This is likely due to the high resistance of bats to pathogenic microorganisms, somehow similar to some rodents (mice, rats). Moreover, this suggests that bats do not get infected by exposure to meat, but rather by exposure to water (and free-living amoebae) as well as to ectoparasites colonizing bats (such as Spinturnix). The latter hypothesis is supported for Chlamydialike organisms by the recent work of Thiévent et al. that demonstrated the occurrence of Chlamydia-related bacteria in several Spinturnix species [35].

\section{Conclusions}

Chlamydiaceae, Chlamydia-like organisms and hemotropic mycoplasmas have been identified in humans and various animal species but only a few studies investigated their presence in bats. This study assessed the prevalence and phylogeny of chlamydial and hemoplasmal DNA in captive and free-living bats from Switzerland, Germany and Costa Rica. Chlamydial and hemoplasmal sequences, similar to sequences obtained from bats and their prey investigated in other studies and from environmental samples, were identified. Newly described sequences indicate that the diversity of these bacteria in bats is broader than previously thought. Neither Chlamydiales nor hemotropic mycoplasmas are restricted to certain bat species or countries, and captive and free-living bats can be colonized.

\section{Methods}

\section{Bat sampling and DNA extraction}

A total number of 475 bats belonging to six bat families and 28 bat species were sampled (Table 1). Lungs, liver, intestines and spleen from 89 captive bats from Switzerland, 28 captive and 55 free-living bats from Germany, and 17 free-living bats from Costa Rica were investigated. Thereof, bat samples from Germany and Costa Rica were obtained from the Department of Wildlife Diseases, Leibniz Institute for Zoo and Wildlife Research, Berlin, Germany and samples from Switzerland were obtained from the Institute of Animal Pathology, Vetsuisse-Faculty, University of Bern, Switzerland, from the Stiftung Papiliorama, Kerzers, Switzerland and from Dr. Danja Wiederkehr, collection curator from the Swiss bat preservation organization. The intestines were selected based on a previous study [9], where Chlamydiae were detected in bat feces. For this study, jejunum was available from the captive bats of Switzerland. Small and large intestines from Swiss free-living bats, captive and free-living bats from Germany and free-living bats from Costa Rica were pooled for DNA extraction. The spleen was selected as target organ for hemotropic mycoplasma detection. Lung and liver were selected because these are common target organs for chlamydial infections in mammals and birds. Moreover, we were interested to 
investigate the systemic (hematogenous) spread of Chlamydiae in these organs.

DNA extraction from bat samples from Switzerland was performed using the DNeasy Blood and Tissue Kit \#69506 (Qiagen, Hilden, Germany) following manufacturer's instructions, whereas DNA extraction of the samples from Germany and Costa Rica was performed using either the NucleoSpin ${ }^{\circ}$ DNA RapidLyse (lung, liver, spleen) or the NucleoSpin ${ }^{\circ}$ Tissue Kit (intestine) (MACHEREY-NAGEL GmbH \& Co. KG, Düren, Germany). Additionally, inner organs including lungs, liver, intestines and spleen, from 285 free-living bats from Switzerland were obtained either as FFPE blocks or fixed in $4 \%$ formalin. The DNA of the FFPE blocks was extracted directly, while the organs fixed in $4 \%$ formalin were first embedded in paraffin according to routine procedures. The DNA extraction was then performed using the QIAamp DNA FFPE Tissue Kit \#56404 (Qiagen) following manufacturer's instructions. DNA quantity and quality of all samples was evaluated by spectrophotometry with the Nanodrop-1000 (Witec AG, Luzern, Switzerland).

\section{PCR analysis for Chlamydiales DNA}

A total of 1021 DNA samples was screened for the presence of Chlamydiales DNA using two different real-time PCRs targeting sequentially the 23S rRNA gene (Chlamydiaceae family-specific) and the 16S rRNA gene (panChlamydiales order-specific).

The Chlamydiaceae-specific real-time PCR targeting the 23S rRNA gene (Chlam23S quantitative polymerase chain reaction, qPCR) [36] used primers Ch23S-F, Ch23S-R and probe Ch23S-p (Microsynth, Balgach, Switzerland) described by Ehricht et al. [37]. The internal amplification control eGFP amplified with primers eGFP-1-F, eGFP-10-R and probe eGFP-Hex (Microsynth) was added to each reaction [38]. The PCR was conducted on a Thermocycler 7500 Fast ABI (Thermo Fisher Scientific). All samples were tested in duplicate and samples with a cycle threshold of $<38$ in duplicate PCR reactions were considered positive. Quantitation was performed using 10-fold dilutions $\left(10^{7}\right.$ copies to 10 copies $\left./ \mu \mathrm{L}\right)$ of the Chlamydia abortus genomic DNA positive control (standard curve).

Samples positive in the Chlamydiaceae familyspecific real-time PCR were then further analysed using three different conventional PCR protocols targeting partial sequences of the $16 \mathrm{~S}$ or $23 \mathrm{~S}$ rRNA gene. The conventional PCR targeting a 278-bp fragment of Chlamydiales 16S rRNA gene (16S-IGF/IGRPCR) was performed using primers 16S-IGF and 16SIGR [39, 40] (Microsynth) modified from Everett et al. [4]. Primers 16S-panCh-F and 16S-panCh-R
(Microsynth) were applied for the conventional PCR targeting a 200-bp fragment of the Chlamydiales $16 \mathrm{~S}$ rRNA gene (16S-pan-PCR) [32] and the conventional PCR targeting a $700 \mathrm{bp}$ fragment of Chlamydiales $23 \mathrm{~S}$ rRNA gene (23SIG-PCR) [4, 32, 36] included primers U23-F and 23SIG-R (Microsynth). For all three conventional PCRs, cycling was performed on a Biometra TRIO Thermal Cycler (Analytik Jena AG, Jena, Germany) and PCR products were analysed by gelelectrophoresis on a $1.5 \%$ agarose gel.

For the pan-Chlamydiales real-time PCR targeting a partial sequence of the $16 \mathrm{~S}$ rRNA-encoding gene (16S-pan-qPCR) [41], primers 16S-panCh-F, 16SpanCh-R and probe 16S-panCh (Eurogentec, Seraing, Belgium) were applied in a StepOne Plus real-time PCR system (Thermo Fisher Scientific). All samples were tested in duplicate, and if a single replicate was positive $(\mathrm{Ct} \leq 37)$, the corresponding sample was considered positive. Quantification was performed using a 10-fold-dilution of a plasmid control tested in duplicate, constructed with the sequence of interest based on the Parachlamydia acanthamoebae 16S rRNA encoding gene, cloned with the TOPO TA Cloning Kit for Subcloning with One Shot TOP10 chemically competent E. coli cells (Thermo Fisher Scientific). Molecular-biology-grade water was used as a negative control in all PCR reactions.

All PCR primers and probes, the targeted genes and amplicon sizes used in this study are summarized in Table 3. All reaction mix compositions and cycling conditions are shown in Table S1.

\section{PCR analysis for hemotropic mycoplasma DNA}

All spleen and FFPE block samples $(n=475)$ from 462 bats were screened for the presence of hemoplasma DNA using a universal hemotropic mycoplasma-specific SYBR Green real-time PCR (Hemoplasma SYBR Green qPCR) targeting the 16S rRNA encoding gene, including primers Mhae_sybr.359f, Mcocc_sybrF, Mhae_sybr.432r and Cmhae_Sybr.493r (Microsynth) [42]. Samples within the same melting temperature range as the positive controls were considered positive.

Samples positive by SYBR Green real-time PCR were then further analysed by using real-time PCRs specific for M. haemofelis-like and 'Candidatus M. haemominutum'-like organisms and two conventional PCRs targeting an 871-bp and 1030-bp region of the 16S rRNA encoding gene.

The M. haemofelis-like-specific real-time PCR (Mhflike qPCR) targeting a 114-bp fragment of the 16S rRNA gene was performed using primers Group_Mhf_fwd and Group_Mhf_rev and probe Group_Mhf_probe (Microsynth) [43]. 
Table 3 Primers and probes used in the present study

\begin{tabular}{|c|c|c|c|c|}
\hline PCR method* & $\begin{array}{l}\text { Gene target \& } \\
\text { amplicon size }\end{array}$ & Name & Sequence $\left(5^{\prime}-3^{\prime}\right)$ & Reference \\
\hline \multirow[t]{3}{*}{ Chlam23S-qPCR } & \multirow[t]{3}{*}{ 23S rRNA, 111 bp } & Ch23S-F & CTGAAACCAGTAGCTTATAAGCGGT & \multirow[t]{3}{*}{ Ehricht et al. 2006 [37] } \\
\hline & & Ch23S-R & ACCTCGCCGTTTAACTTAACTCC & \\
\hline & & Ch23S-p & $\begin{array}{l}\text { 6-FAM-CTCATCATGCAAAAGGCA } \\
\text { CGCCG-TAMRA }\end{array}$ & \\
\hline \multirow[t]{2}{*}{ 23SIG-PCR } & \multirow[t]{2}{*}{$\begin{array}{l}23 \mathrm{~S} \text { rRNA signature } \\
\text { sequence, } 700 \mathrm{bp}\end{array}$} & U23-F & $\begin{array}{l}\text { GATGCCTTGGCATTGATAGGCG } \\
\text { ATGAAGGA }\end{array}$ & \multirow[t]{2}{*}{ Everett et al. $1999[4,36]$} \\
\hline & & $23 S I G-R$ & TGGCTCATCATGCAAAAGGCA & \\
\hline \multirow[t]{2}{*}{ 16S-IGF/IGR-PCR } & \multirow[t]{2}{*}{$16 \mathrm{~S}$ rRNA, $278 \mathrm{bp}$} & 16S-IGF & GATGAGGCATGCAAGTCGAACG & \multirow{2}{*}{$\begin{array}{l}\text { Pospischil et al. } 2012 \text { [39]; Blumer } \\
\text { et al. } 2007 \text { [40] }\end{array}$} \\
\hline & & 16S-IGR & CCAGTGTTGGCGGTCAATCTCTC & \\
\hline \multirow{5}{*}{$\begin{array}{l}\text { 16S-pan-qPCR } \\
\text { 16S-pan-PCR }\end{array}$} & \multirow[t]{3}{*}{$16 \mathrm{~S} r \mathrm{RNA}, 200 \mathrm{bp} \mathrm{a}^{\mathrm{a}, \mathrm{b}}$} & 16S-panCh-F $F^{a, b}$ & CCGCAACACTGGGACT & \multirow{5}{*}{$\begin{array}{l}\text { Lienard et al. } 2011 \text { [41] }^{\mathrm{a}} \text {, Hokynar } \\
\text { et al. 2016 }{ }^{\mathrm{b}}[32]\end{array}$} \\
\hline & & 16S-panCh-R $\mathrm{R}^{\mathrm{a}, \mathrm{b}}$ & GGAGTTAGCCGGTGCTTCTITAC & \\
\hline & & 16S-panCh ${ }^{a}$ & $\begin{array}{l}\text { 6-FAM-CTACGGGAGGCTGCAGTC } \\
\text { GAGAATC-BHQ1 }\end{array}$ & \\
\hline & \multirow[t]{2}{*}{ sequencing primers ${ }^{\mathrm{a}}$} & panFseq $^{a}$ & CCAACACTGGGACTGAGA & \\
\hline & & panRseq $^{a}$ & GCCGGTGCTTCTTTAC & \\
\hline \multirow[t]{3}{*}{ eGFP-qPCR } & \multirow[t]{3}{*}{ eGFP, 177 bp } & eGFP-1-F & GACCACTACCAGCAGAACAC & \multirow[t]{3}{*}{ Blumer et al. 2011 [38] } \\
\hline & & eGFP-10-R & CTTGTACAGCTCGTCCATGC & \\
\hline & & eGFP-Hex & $\begin{array}{l}\text { VIC-AGCACCCAGTCCGCCCTGAGCA- } \\
\text { none }\end{array}$ & \\
\hline \multirow{4}{*}{$\begin{array}{l}\text { Hemoplasma SYBR } \\
\text { Green qPCR }\end{array}$} & \multirow[t]{4}{*}{$16 \mathrm{~S}$ rRNA } & Mhae_sybr.359f & AGCAATACCATGTGAACGATGAA & \multirow[t]{4}{*}{ Willi et al. 2009 [42] } \\
\hline & & Mcocc_sybrF & AGCAATGCCATGTGAACGATGAA & \\
\hline & & Mhae_sybr.432r & TGGCACATAGTTTGCTGTCACTT & \\
\hline & & $\begin{array}{l}\text { Cmhae_ } \\
\text { Sybr.493r }\end{array}$ & GCTGGCACATAGTTAGCTGTCACT & \\
\hline \multirow[t]{3}{*}{ Mhf-like qPCR } & \multirow[t]{3}{*}{$16 \mathrm{~S}$ rRNA, $114 \mathrm{bp}$} & Group_Mhf_fwd & GGAGCGGTGGAATGTGTAG & \multirow[t]{3}{*}{ Tasker et al. 2010 [43] } \\
\hline & & Group_Mhf_rev & GGGGTATCTAATCCCATTTGC & \\
\hline & & $\begin{array}{l}\text { Group_Mhf_ } \\
\text { probe }\end{array}$ & $\begin{array}{l}\text { 6-FAM-TYAAGAACACCAGAGGCGAA } \\
\text { GGCG-BHQ1 }\end{array}$ & \\
\hline \multirow[t]{3}{*}{ CMmh-like qPCR } & \multirow[t]{3}{*}{ 16S rRNA, $139 \mathrm{bp}$} & $\begin{array}{l}\text { Group_CMhm_ } \\
\text { fwd }\end{array}$ & GGGGCCAAGTCAAGTCATC & \multirow[t]{3}{*}{ Tasker et al. 2010 [43] } \\
\hline & & $\begin{array}{l}\text { Group_CMhm_ } \\
\text { rev }\end{array}$ & GCGAATTGCAGCCTITTATC & \\
\hline & & $\begin{array}{l}\text { Group_CMhm_ } \\
\text { probe }\end{array}$ & $\begin{array}{l}\text { YYE-TACCATTGTAGCACGTTY } \\
\text { GCAGCCC-BHQ1 }\end{array}$ & \\
\hline \multirow[t]{2}{*}{ HemMycop41/938-PCR } & \multirow[t]{2}{*}{$16 \mathrm{~S}$ rRNA, $871 \mathrm{bp}$} & $\begin{array}{l}\text { HemMycop16S- } \\
41 \mathrm{~s}\end{array}$ & $\begin{array}{l}\text { GYAT } \\
\text { GCMTAAYACATGCAAGTCGARCG }\end{array}$ & \multirow[t]{2}{*}{ Mascarelli et al. 2014 [21] } \\
\hline & & $\begin{array}{l}\text { HemMycop16S- } \\
\text { 938as }\end{array}$ & CTCCACCACTTGTTCAGGTCCCCGTC & \\
\hline \multirow[t]{2}{*}{$\begin{array}{l}\text { HemMycop322/1420- } \\
\text { PCR }\end{array}$} & \multirow[t]{2}{*}{ 16S rRNA, $1030 \mathrm{bp}$} & $\begin{array}{l}\text { HemMycop16S- } \\
322 \mathrm{~s}\end{array}$ & $\begin{array}{l}\text { GCCCATATTCCTACGGGAAGCA } \\
\text { GCAGT }\end{array}$ & \multirow[t]{2}{*}{ Mascarelli et al. 2014 [21] } \\
\hline & & $\begin{array}{l}\text { HemMycop16S- } \\
\text { 1420as }\end{array}$ & GTTGACGGGCGGTGTGTACAAGACC & \\
\hline
\end{tabular}

*conventional PCR (PCR), real-time PCR (qPCR)

a $\&$ b PCRs performed according to the respective labeled reference, using the respective labeled primers

The 'Candidatus M. haemominutum'-like-specific real-time PCR (CMhm-like qPCR) targeting a 139-bp fragment of the $16 \mathrm{~S}$ rRNA gene included primers Group_CMhm_fwd and Group_CMhm_rev and probe Group_CMhm-probe (Microsynth) [43].
All three real-time PCRs were conducted on a Thermocycler 7500-Fast ABI. Molecular-biology-grade water was used as a negative PCR control and DNA of Mycoplasma haemofelis, 'Candidatus Mycoplasma haemominutum', 'Candidatus Mycoplasma turicensis' and 
'Candidatus Mycoplasma haematoparvum' was used as a positive PCR control.

The conventional PCR targeting an 871-bp fragment of hemoplasmal 16S rRNA encoding gene (HemMycop41/ 938-PCR) was performed using primers HemMycop16S$41 \mathrm{~s}$ and HemMycop16S-938as (Microsynth). Primers HemMycop16S-322 s and HemMycop16S-1420as (Microsynth) were applied for the conventional PCR targeting a 1030-bp fragment of the hemoplasmal 16S rRNA encoding gene (HemMycop322/1420-PCR) [21]. Molecularbiology-grade water was used as a negative PCR control and DNA from both Mycoplasma wenyonii and Mycoplasma haemocanis were used as positive PCR controls. Cycling was performed on a Biometra T-personal Thermal Cycler (Biolabo Scientific Instruments, Châtel-SaintDenis, Switzerland) and PCR products were analysed by gel-electrophoresis on a $1.5 \%$ agarose gel.

All PCR primers and probes, the targeted genes and amplicon sizes used in this study are summarized in Table 3. All reaction mix compositions and cycling conditions are shown in Table S1.

\section{Sequencing and analysing of Chlamydiales- and Hemoplasma-positive PCR products}

For sequencing, amplicons of samples positive by conventional PCRs 16S-IGF/IGR-PCR, 16S-pan-PCR, 23SIG-PCR, HemMycop41/938-PCR or HemMycop322/ 1420-PCR were purified using the GeneJET PCR Purification Kit (ThermoFisher Scientific) or the GeneJET Gel Extraction Kit (ThermoFisher Scientific) according to manufacturer's instructions. The forward and reverse strands of the PCR products were sequenced using the respective primers of the positive PCR reaction. Microsynth performed all sequencing reactions using Sanger sequencing.

Amplicons of samples positive by 16S-pan-qPCR with a $\mathrm{Ct}$ value $\leq 35.0$ were a) either purified using an MSB Spin PCRapace kit (Invitek, Berlin, Germany) with a subsequent PCR reaction using a BigDye Terminator v1.1 cycle sequencing kit (Applied Biosystems) [41] or b) purified and sequenced by Microsynth using specifically designed inner primers panFseq and panRseq.

Sequence traces were visualized and assembled in CLC Genomics Workbench v10.1.1; assemblies were compared to known sequences in the NCBI database by BLAST analysis. Phylogenetic analyses on the assemblies and related database sequences were performed using muscle with default parameters in Seaview (44) with manual correction where necessary to create alignments, and using PhyML in Seaview with default parameters including GTR model, and 100 bootstrap replicates, to create phylogenetic trees.

\section{Supplementary information}

Supplementary information accompanies this paper at https://doi.org/10. 1186/s12866-020-01872-x.

Additional file 1: Supplementary Table 1. Reaction Mix compositions and cycling conditions of PCR methods used in this study.

\section{Abbreviations}

16S rRNA: 165 ribosomal ribonucleic acid; 235 rRNA: 235 ribosomal ribonucleic acid; bp: Base pair; qPCR: Quantitative polymerase chain reaction; PCR: Polymerase chain reaction

\section{Acknowledgments}

Many thanks go to the team of the Institute of Animal Pathology, University of Bern, namely Kerstin Hahn, Corinne Gurtner and Marion Schediwy for performing necropsy and organ sampling of the captive bats in Switzerland. We thank Theresa Pesch, Barbara Prähauser, Lea Rohner, Benita Pineroli and Nadine Jahn for their technical assistance with laboratory work, which was partly performed using the logistics of the Center for Clinical Studies at the Vetsuisse Faculty of the University of Zurich. We also thank Gudrun Wibbelt for the provision of bat samples from Germany and Costa Rica and Caspar Bijleveld and Line Destraz for the provision of bat samples from the Papiliorama in Kerzers.

\section{Authors' contributions}

NB and NSR designed and planned the study. JF, KM, NSR, DW and PVDB collected the samples. JF, HM, HMBS, SA, GG, MLM, RHL, PP and NB performed data analyses and interpretation. JF and NB draft the manuscript. All authors read and approved the final manuscript.

\section{Funding}

This research received no specific grant from any funding agency in the public, commercial, or not-for-profit sectors.

\section{Availability of data and materials}

The sequences obtained in this study were deposited in the GenBank under accession numbers LR699022.1, LR699021.1, LR699020.1, LR584972.1, LR584971.1, LR584970.1; LR584969.1, LR584968.1, LR584967.1, LR584966.1, LR584965.1, released under the project 546195: https://www.ncbi.nlm.nih. gov/nuccore?term $=546195 \% 5 B$ BioProject\%5D

\section{Ethics approval and consent to participate}

We obtained written informed consent to use bat samples from the Department of Wildlife Diseases, Leibniz Institute for Zoo and Wildlife Research, Berlin, Germany, from the Institute of Animal Pathology, Vetsuisse-Faculty, University of Bern, Switzerland, from the Stiftung Papiliorama, Kerzers, Switzerland and from Dr. Danja Wiederkehr.

\section{Consent for publication}

Not applicable.

\section{Competing interests}

The authors declare that they have no competing interests.

\section{Author details}

${ }^{1}$ Institute of Veterinary Pathology, Vetsuisse Faculty, University of Zurich, Zurich, Switzerland. ${ }^{2}$ Center for Clinical Studies, Vetsuisse Faculty, University of Zurich, Zurich, Switzerland. ${ }^{3}$ Institute of Microbiology, University of Lausanne, Zurich, Switzerland. ${ }^{4}$ Clinical Laboratory, Department for Clinical Diagnostics and Services, Vetsuisse Faculty, University of Zurich, Zurich, Switzerland. ${ }^{5}$ Department of Wildlife Diseases, Leibniz Institute for Zoo and Wildlife Research, Berlin, Germany. ${ }^{6}$ Institute of Animal Pathology, Vetsuisse-Faculty, University of Bern, Bern, Switzerland. ${ }^{7}$ Bern University of Applied Sciences, School of Agricultural, Forest and Food Sciences, Zollikofen, Switzerland. ${ }^{8}$ Institute of Veterinary Bacteriology, Vetsuisse Faculty, University of Bern, Bern, Switzerland. ${ }^{9}$ Stiftung Papiliorama, Kerzers, Switzerland. 
Received: 22 January 2020 Accepted: 23 June 2020

Published online: 26 June 2020

\section{References}

1. Mühldorfer K. Bats and bacterial pathogens: a review. Zoonoses Public Health. 2013;60:93-103. https://doi.org/10.1111/j.1863-2378.2012.01536.x.

2. Kuzmin IV, Bozick B, Guagliardo SA, Kunkel R, Shak JR, Tong S, Rupprecht CE. Bats, emerging infectious diseases, and the rabies paradigm revisited. Emerg Health Threats J. 2011;4:7159. https://doi.org/10.3402/ehtj.v4i0.7159.

3. Rurangirwa FR, Dilbeck PM, Crawford TB, McGuire TC, McElwain TF. Analysis of the 165 rRNA gene of micro-organism WSU 86-1044 from an aborted bovine foetus reveals that it is a member of the order Chlamydiales: proposal of Waddliaceae fam. nov., Waddlia chondrophila gen. nov., sp. nov. Int J Syst Bacteriol. 1999;49 Pt 2:577-81. https://doi.org/10.1099/0020771349-2-577.

4. Everett KD, Bush RM, Andersen AA. Emended description of the order Chlamydiales, proposal of Parachlamydiaceae fam. nov. and Simkaniaceae fam. Nov., each containing one monotypic genus, revised taxonomy of the family Chlamydiaceae, including a new genus and five new species, and standards for the identification of organisms. Int J Syst Bacteriol. 1999:49 Pt 2:415-40. https://doi.org/10.1099/00207713-49-2-415.

5. Taylor-Brown A, Vaughan L, Greub G, Timms P, Polkinghorne A. Twenty years of research into chlamydia-like organisms: a revolution in our understanding of the biology and pathogenicity of members of the phylum Chlamydiae. Pathog Dis. 2015;73:1-15. https://doi.org/10.1093/femspd/ ftu009.

6. Greub G, Raoult D. Crescent bodies of Parachlamydia acanthamoeba and its life cycle within Acanthamoeba polyphaga. An electron micrograph study. Appl Environ Microbiol. 2002;68:3076-84. https://doi.org/10.1128/aem.68.6. 3076-3084.2002.

7. Chua PKB, Corkill JE, Hooi PS, Cheng SC, Winstanley C, Hart CA. Isolation of Waddlia malaysiensis, a novel intracellular bacterium, from fruit bat (Eonycteris spelaea). Emerg Infect Dis. 2005;11:271-7. https://doi.org/10. 3201/eid1102.040746.

8. Pierlé SA, Morales CO, Martínez LP, Ceballos NA, Rivero JJP, Díaz OL, Brayton KA, Setién AA. Novel Waddlia intracellular bacterium in Artibeus intermedius fruit bats, Mexico. Emerg Infect Dis. 2015;21:2161-3. https://doi.org/10.3201/ eid2112.150002

9. Hokynar K, Vesterinen EJ, Lilley TM, Pulliainen AT, Korhonen SJ, Paavonen J, Puolakkainen M. Molecular evidence of chlamydia-like organisms in the feces of Myotis daubentonii bats. Appl Environ Microbiol. 2017;83. https:// doi.org/10.1128/AEM.02951-16.

10. Messick JB. Hemotrophic mycoplasmas (hemoplasmas): a review and new insights into pathogenic potential. Vet Clin Pathol. 2004:33:2-13.

11. Rosenberg E, DeLong EF, Lory S, Stackebrandt E, Thompson F, editors. The prokaryotes. Firmicutes and Tenericutes, 4. ed. Berlin: Springer; 2014

12. Museux K, Boretti FS, Willi B, Riond B, Hoelzle K, Hoelzle LE, Wittenbrink MM, Tasker S, Wengi N, Reusch CE, Lutz H, Hofmann-Lehmann R. In vivo transmission studies of 'Candidatus mycoplasma turicensis' in the domestic cat. Vet Res. 2009:40:45. https://doi.org/10.1051/vetres/2009028.

13. Dean RS, Helps CR, Gruffydd Jones TJ, Tasker S. Use of real-time PCR to detect mycoplasma haemofelis and 'Candidatus mycoplasma haemominutum' in the saliva and salivary glands of haemoplasma-infected cats. J Feline Med Surg. 2008;10:413-7. https://doi.org/10.1016/j.jfms.2007.12.007.

14. Willi B, Boretti FS, Cattori V, Tasker S, Meli ML, Reusch C, Lutz H, HofmannLehmann R. Identification, molecular characterization, and experimental transmission of a new Hemoplasma isolate from a cat with hemolytic Anemia in Switzerland. J Clin Microbiol. 2005;43:2581-5. https://doi.org/10. 1128/JCM.43.6.2581-2585.2005.

15. Hoelzle LE. Haemotrophic mycoplasmas: recent advances in mycoplasma suis. Vet Microbiol. 2008;130:215-26. https:/doi.org/10.1016/j.vetmic.2007.12.023.

16. Dieckmann SM, Winkler M, Groebel K, Dieckmann MP, Hofmann-Lehmann R, Hoelzle K, Wittenbrink MM, Hoelzle LE. Haemotrophic mycoplasma infection in horses. Vet Microbiol. 2010;145:351-3. https://doi.org/10.1016/j.vetmic. 2010.04.009

17. Maggi RG, Chitwood MC, Kennedy-Stoskopf S, DePerno CS. Novel hemotropic mycoplasma species in white-tailed deer (Odocoileus virginianus). Comp Immunol Microbiol Infect Dis. 2013;36:607-11. https:// doi.org/10.1016/j.cimid.2013.08.001.

18. Willi B, Filoni C, Catão-Dias JL, Cattori V, Meli ML, Vargas A, Martínez F, Roelke ME, Ryser-Degiorgis M-P, Leutenegger CM, Lutz H, Hofmann-
Lehmann R. Worldwide occurrence of feline Hemoplasma infections in wild felid species. J Clin Microbiol. 2007:45:1159-66. https://doi.org/10.1128/JCM. 02005-06

19. Yang D, Tai X, Qiu Y, Yun S. Prevalence of Eperythrozoon spp. infection and congenital eperythrozoonosis in humans in Inner Mongolia, China. Epidemiol Infect. 2000;125:421-6.

20. Ikeda P, Seki MC, Carrasco AOT, Rudiak LV, Miranda JMD, Gonçalves SMM, Hoppe EGL, Albuquerque ACA, Teixeira MMG, Passos CE, Werther K, Machado RZ, André MR. Evidence and molecular characterization of Bartonella spp. and hemoplasmas in neotropical bats in Brazil. Epidemiol Infect. 2017;145:2038-52. https://doi.org/10.1017/S0950268817000966.

21. Mascarelli PE, Keel MK, Yabsley M, Last LA, Breitschwerdt EB, Maggi RG. Hemotropic mycoplasmas in little brown bats (Myotis lucifugus). Parasit Vectors. 2014;7:117. https://doi.org/10.1186/1756-3305-7-117.

22. Millán J, López-Roig M, Delicado V, Serra-Cobo J, Esperón F. Widespread infection with hemotropic mycoplasmas in bats in Spain, including a hemoplasma closely related to "Candidatus mycoplasma hemohominis". Comp Immunol Microbiol Infect Dis. 2015;39:9-12. https://doi.org/10.1016/j. cimid.2015.01.002

23. Volokhov DV, Becker DJ, Bergner LM, Camus MS, Orton RJ, Chizhikov VE, Altizer SM, Streicker DG. Novel hemotropic mycoplasmas are widespread and genetically diverse in vampire bats. Epidemiol Infect. 2017;145:3154-67. https://doi.org/10.1017/S095026881700231X.

24. Pillonel T, Bertelli C, Salamin N, Greub G. Taxogenomics of the order Chlamydiales. Int J Syst Evol Microbiol. 2015;65:1381-93. https://doi.org/10. 1099/ijs.0.000090.

25. Millán J, Cevidanes A, Sacristán I, Alvarado-Rybak M, Sepúlveda G, RamosMella CA, Lisón F. Detection and characterization of Hemotropic mycoplasmas in bats in Chile. J Wildl Dis. 2019;55:977-81.

26. Dietrich M, Mühldorfer K, Tortosa P, Markotter W. Leptospira and bats. Story of an emerging friendship. PLoS Pathog. 2015;11:e1005176. https://doi.org/ 10.1371/journal.ppat.1005176.

27. Stuckey MJ, Chomel BB, de Fleurieu EC, Aguilar-Setién A, Boulouis H-J, Chang C-C. Bartonella, bats and bugs. A review. Comp Immunol Microbiol Infect Dis. 2017:55:20-9. https://doi.org/10.1016/j.cimid.2017.09.001.

28. Hornok S, Szőke K, Estók P, Krawczyk A, Haarsma A-J, Kováts D, Boldogh SA, Morandini P, Szekeres S, Takács N, Kontschán J, Meli ML, Fernández de Mera IG, de la Fuente J, Gyuranecz M, Sulyok KM, Weibel B, Gönczi E, de Bruin A, Sprong $H$, Hofmann-Lehmann R. Assessing bat droppings and predatory bird pellets for vector-borne bacteria. Molecular evidence of bat-associated Neorickettsia sp. in Europe. Antonie Van Leeuwenhoek. 2018;111:1707-17. https://doi.org/10.1007/s10482-018-1043-7.

29. Wheelhouse N, Sait M, Gidlow J, Deuchande R, Borel N, Baily J, Caldow G, Longbottom D. Molecular detection of chlamydia-like organisms in cattle drinking water. Vet Microbiol. 2011;152:196-9. https://doi.org/10.1016/j. vetmic.2011.03.040.

30. Corsaro D, Müller K, Wingender J, Michel R. "Candidatus Mesochlamydia elodeae" (Chlamydiae: Parachlamydiaceae), a novel chlamydia parasite of free-living amoebae. Parasitol Res. 2013;112:829-38. https://doi.org/10.1007/ s00436-012-3213-2.

31. Codony F, Fittipaldi M, López E, Morató J, Agustí G. Well water as a possible source of Waddlia chondrophila infections. Microbes Environ. 2012;27:529-32.

32. Hokynar K, Sormunen JJ, Vesterinen EJ, Partio EK, Lilley T, Timonen V, Panelius J, Ranki A, Puolakkainen M. Chlamydia-like organisms (CLOs) in Finnish Ixodes ricinus ticks and human skin. Microorganisms. 2016;4. https:// doi.org/10.3390/microorganisms4030028.

33. Pilloux L, Aeby S, Gaumann R, Burri C, Beuret C, Greub G. The high prevalence and diversity of Chlamydiales DNA within Ixodes ricinus ticks suggest a role for ticks as reservoirs and vectors of chlamydia-related Bacteria. Appl Environ Microbiol. 2015;81:8177-82. https://doi.org/10.1128/ AEM.02183-15.

34. Croxatto A, Rieille N, Kernif T, Bitam I, Aeby S, Péter O, Greub G. Presence of Chlamydiales DNA in ticks and fleas suggests that ticks are carriers of Chlamydiae. Ticks Tick Borne Dis. 2014;5:359-65. https://doi.org/10.1016/j. ttbdis.2013.11.009.

35. Thiévent K, Szentiványi T, Aeby S, Glaizot O, Christe P, Greub G. Presence of chlamydia-like organisms (CLOs) in Spinturnix myoti, an ectoparasite of bats; 2019

36. Everett KD, Hornung $L$, Andersen AA. Rapid detection of the Chlamydiaceae and other families in the order Chlamydiales: three PCR tests. J Clin Microbiol. 1999;37:575-80. 
37. Ehricht R, Slickers P, Goellner S, Hotzel H, Sachse K. Optimized DNA microarray assay allows detection and genotyping of single PCR-amplifiable target copies. Mol Cell Probes. 2006;20:60-3. https://doi.org/10.1016/j.mcp. 2005.09.003.

38. Blumer S, Greub G, Waldvogel A, Hässig M, Thoma R, Tschuor A, Pospischil A, Borel N. Waddlia, Parachlamydia and Chlamydiaceae in bovine abortion. Vet Microbiol. 2011;152:385-93. https://doi.org/10.1016/j.vetmic.2011.05.024.

39. Pospischil A, Kaiser C, Hofmann-Lehmann R, Lutz H, Hilbe M, Vaughan L, Borel N. Evidence for chlamydia in wild mammals of the Serengeti. J Wildl Dis. 2012;48:1074-8. https://doi.org/10.7589/2011-10-298.

40. Blumer C, Zimmermann DR, Weilenmann R, Vaughan L, Pospischil A. Chlamydiae in free-ranging and captive frogs in Switzerland. Vet Pathol. 2007:44:144-50. https://doi.org/10.1354/vp.44-2-144.

41. Lienard J, Croxatto A, Aeby S, Jaton K, Posfay-Barbe K, Gervaix A, Greub G. Development of a new Chlamydiales-specific real-time PCR and its application to respiratory clinical samples. J Clin Microbiol. 2011;49:2637-42. https://doi.org/10.1128/JCM.00114-11.

42. Willi B, Meli ML, Lüthy R, Honegger H, Wengi N, Hoelzle LE, Reusch CE, Lutz H, Hofmann-Lehmann R. Development and application of a universal Hemoplasma screening assay based on the SYBR green PCR principle. J Clin Microbiol. 2009:47:4049-54. https://doi.org/10.1128/JCM.01478-09.

43. Tasker S, Peters IR, Mumford AD, Day MJ, Gruffydd-Jones TJ, Day S, Pretorius A-M, Birtles RJ, Helps CR, Neimark H. Investigation of human haemotropic mycoplasma infections using a novel generic haemoplasma qPCR assay on blood samples and blood smears. J Med Microbiol. 2010;59:1285-92. https://doi.org/10.1099/jmm.0.021691-0.

\section{Publisher's Note}

Springer Nature remains neutral with regard to jurisdictional claims in published maps and institutional affiliations.

Ready to submit your research? Choose BMC and benefit from:

- fast, convenient online submission

- thorough peer review by experienced researchers in your field

- rapid publication on acceptance

- support for research data, including large and complex data types

- gold Open Access which fosters wider collaboration and increased citations

- maximum visibility for your research: over $100 \mathrm{M}$ website views per year

At $\mathrm{BMC}$, research is always in progress.

Learn more biomedcentral.com/submissions 